\title{
Fine structure and function of the genital pore of the female of Intoshia variabili (Orthonectida)
}

\author{
George S. Slyusarev
}

Department of Invertebrate Zoology, Faculty of Biology and Soil Science, Saint-Petersburg State University, Universitetskaya nab. 7/9, Saint-Petersburg 199034, Russia

Key words: Orthonectida, genital pore, fine structure

\begin{abstract}
The genital pore of the female of Intoshia variabili Aleksandrov et Sljusarev, 1992 is located on a transverse ring of non-ciliated cells. Before copulation it is occupied by 6-7 cells that develop in the epithelium and that for a time are beneath the surface. When fully developed, these cells contain many electron-dense granules and their apical surface is covered with numerous microvilli. After copulation the granules disappear and the apical surface becomes smooth. The cells still form a plug closing the opening. After one larva pushes the pore cells out and escapes, others follow.
\end{abstract}

The phylum Orthonectida is a small and in many respects an enigmatic group of parasites of uncertain phylogenetic relations. It is also not clear if they are primitive organisms or highly specialised parasites with structural reduction of general organisation. They utilise a wide range of marine invertebrates as hosts including turbellarians, nemertines, annelids, molluscs, echinoderms and even ascidians. The life cycle of orthonectids consists of a parasitic plasmodium stage in which sexual stages develop. Larvae develop inside the female and when ready emerge to infect a new host. The morphology of orthonectids is only incompletely known and fine structure of males and females has been described for only a few species of Orthonectida (Kozloff 1969, 1971, Slyusarev 1994, Slyusarev and Miller 1998).

Silver impregnation demonstrating the arrangement of epidermal cells and used for accurate description of orthonectid species reveals the presence of a genital pore in most males and females (Kozloff 1992). The term "genital pore" was first proposed by Caullery and Mesnil (1901) to mark the place of gamete exchange. Henri Nouvel (Nouvel 1935), who was the first to use silver impregnation, showed its presence in Rhopalura ophiocomae and $R$. linei. Usually it is situated in the middle part of the body in a non-ciliated ring of epidermal cells (the body of orthonectids is covered by a single layer of transverse rings of ciliated cells alternating with rings of non-ciliated cells). In all examined species of Orthonectida the genital pore is occupied by very small cells that are $2-3$ times smaller than the epidermal cells. The number of cells filling the genital pore in different species varies; it is usually 6-7, sometimes up to 9 . Genital pore cells have been shown to contain granules (Slyusarev 1994). Fine structure of the genital pore, however, is unknown and its function is not clear.
A description of genital pore fine structure and its modification during the life cycle of the female of the orthonectid Intoshia variabili Aleksandrov et Sljusarev, 1992 is provided in the present paper.

\section{MATERIALS AND METHODS}

The orthonectid Intoshia variabili occurs in the turbellarian Macrorhynchus crocea (Fabricius, 1826) Graff, 1982 (Plathelminthes: Calyptorhynchia). Material for the present study was collected in July 1998 in the Bay of Chupa, the White Sea, just northeast of the Marine Biological Station of St. Petersburg State University $\left(66^{\circ} 17^{\prime} \mathrm{N}, 33^{\circ} 40^{\prime} \mathrm{E}\right)$, in $0-1 \mathrm{~m}$ depth. Turbellarians were collected from clumps of Fucus spp. placed in buckets. Detailed procedures for collecting, maintaining and culturing samples of I. variabili to maturity are described in Slyusarev (1994). Worms were fixed in $4 \%$ glutaraldehyde in $0.1 \mathrm{M}$ sodium cacodylate buffer, $\mathrm{pH}$ 7.3, with $6.85 \%$ sucrose for $1 \mathrm{~h}$, then transferred to $1 \%$ osmium tetroxide in the same buffer, also for $1 \mathrm{~h}$. After fixation the material was rinsed in $0.1 \mathrm{M}$ sodium cacodylate buffer, dehydrated in a graded series of ethanol, and embedded in Epon 812. The sections for TEM microscopy were cut on a Reichert-Jung Ultracut E ultramicrotome at the central Electron Microscopic Facilities at Southern Illinois University, Carbondale, Illinois, USA, where they were examined with a Hitachi $\mathrm{H} 500 \mathrm{H}$ transmission electron microscope. Part of the material was studied in the Department of Zoomorphology, Zoological Institute, University of Copenhagen, with a JEOL JEM 100SX transmission electron microscope; some females were sectioned on the same type of ultramicrotome. Altogether, eight females at different stages of development were examined.

\section{RESULTS}

\section{The genital pore in a non-fertilized female}

The genital pore cells arise in the female of $I$. variabili rather late in the development, after the surface 


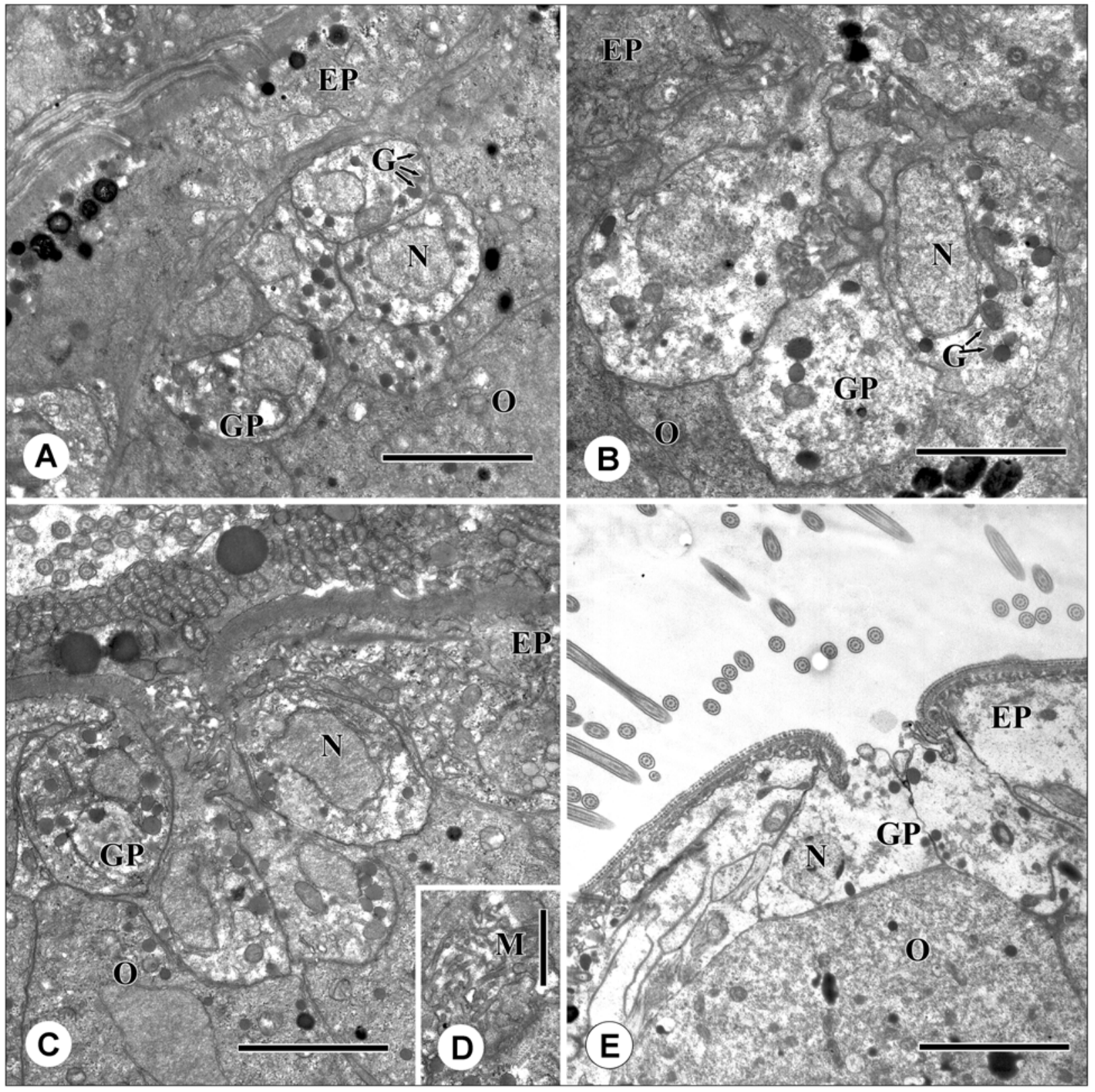

Fig. 1. The genital pore of Intoshia variabili. A, B - formation of genital pore during embryonic development; $\mathbf{C}$ - genital pore before copulation; D - microvilli of genital pore; E - genital pore after copulation. Abbreviations: EP - epithelial cell; G granules; GP - genital pore; $\mathrm{M}$ - microvilli; $\mathrm{N}$ - nucleus; $\mathrm{O}$ - oocyte. Scale bars: $\mathrm{A}, \mathrm{C}-\mathrm{E}=0.5 \mu \mathrm{m} ; \mathrm{B}=0.3 \mu \mathrm{m}$.

layer of ciliated and non-ciliated cells has already differentiated. At first they form a compact group of 6-7 rounded cells of medium size, located under the surface of the epithelial cells (Figs. 1A, 2A). The vesicular nuclei of these cells are relatively large with respect to dimensions of the cells themselves. The cytoplasm contains numerous granules. In the course of development the apical surfaces of the genital pore cells form a slight depression on the body (Fig. 2B). At the same time numerous interlacing microvilli $0.5 \mu \mathrm{m}$ long and $0.01 \mu \mathrm{m}$ in diameter are formed on the apical surface of the genital pore cells (Figs. 1B, C, D, 2B). The cells become more elongated, and their basal portions are widened and are in contact with oocytes (Fig. 2B). Their cytoplasm contains electron-dense secretory granules, mitochondria, lipid inclusions and a well-developed endoplasmic reticulum. The nuclei of the genital pore cells are located in the basal portions.

A completely formed genital pore of a female is occupied by 6-7 small cells compactly arranged like sections of an orange. It is noteworthy that there is no real opening in I. variabili because the genital pore cells 

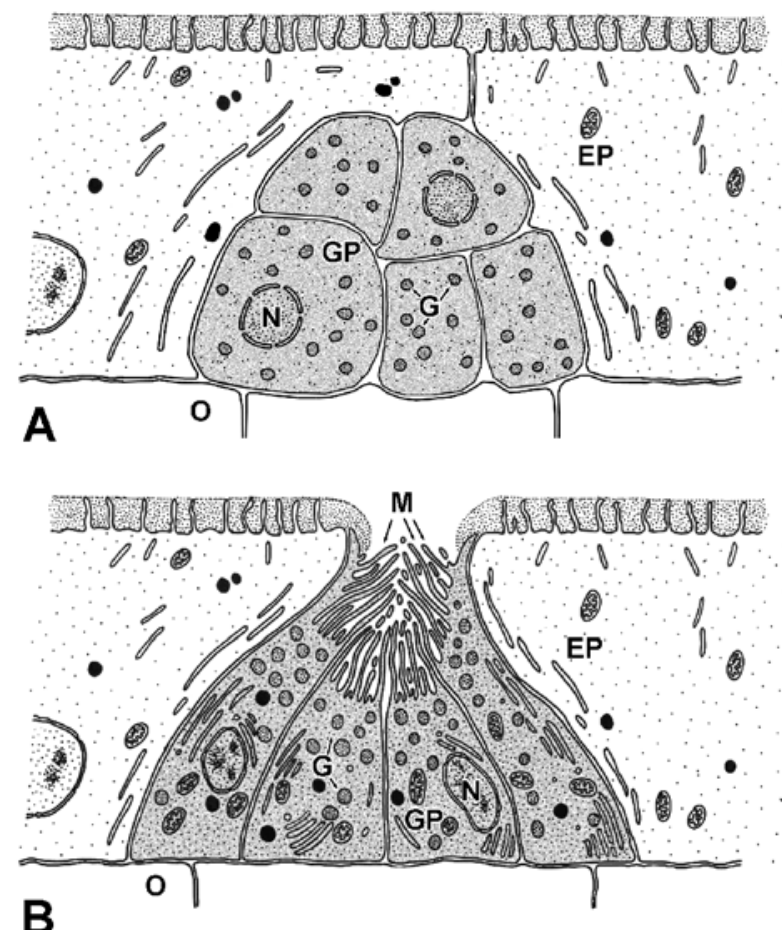

B

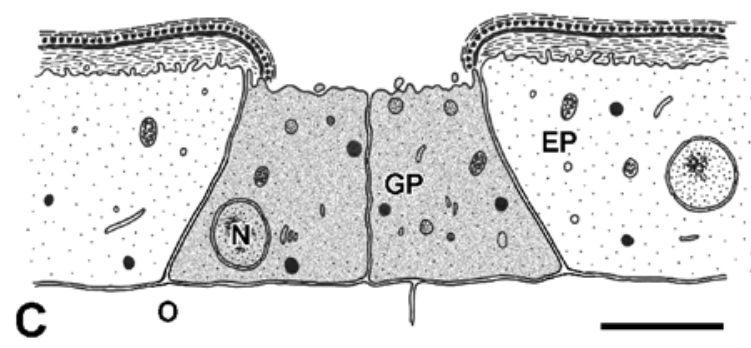

Fig. 2. Schematic representation of the genital pore structure in Intoshia variabili. A - genital pore anlagen in embryo; B genital pore before copulation; C - genital pore after copulation. Abbreviations: EP - epithelial cell; G - granules; $\mathrm{GP}$ - genital pore; $\mathrm{M}$ - microvilli; $\mathrm{N}$ - nucleus; $\mathrm{O}$ - oocyte. Scale bar $=0.4 \mu \mathrm{m}$.

are tightly apposed (Figs. 1C, 2B). It should also be noted that the apical surface of the genital pore cells is not covered by a cuticle; it is, in fact, the only place on the whole body that lacks a cuticle (Figs. 1C, 2B). Neither between the genital pore cells, nor between the genital pore cells and the epithelial cells surrounding them, have any specialised cellular contacts of the desmosome type been found; such contacts are clearly visible between epithelial cells. The whole process of genital pore formation is completed before the female $I$. variabili separates from plasmodium in which she has developed.

The genital pore in a fertilized female

Copulation in I. variabili takes no longer than 30-40 s. After fertilisation (oocyte cleavage serving an indication of successful fertilisation) the structure of genital pore cells is changed. The genital pore cells become flattened (Figs. 1E, 2C). The long microvilli on their surfaces disappear and only single short ones are left. The secretory granules are no longer visible and endoplasmic reticulum disappears as well. The nuclei become pycnotic.

Observations of living females show that the genital pore serves as a place for the exit of larvae from the female. The first larva leaving the maternal organism pushes the genital pore cells out without damaging the surrounding epithelial ciliated cells and emerges. Within 10-30 min all the rest of the larvae emerge one by one through this opening, while the female goes on swimming.

\section{DISCUSSION}

Copulation in Intoshia variabili appears to be similar to copulation in $I$. linei as described by Haloti and Vernet (1995), the only difference being that both males and females of $I$. variabili move more slowly and their contact is longer, about $70-80 \mathrm{~s}$. The males of $I$. variabili, as of all other orthonectid species, lack specialised copulative organs. There is no genuine internal fertilisation, according to our observations. Supporting this is the absence of the cuticle in the genital pore region, where sperm penetration takes place.

Extrusion of secretory granules present in the genital pore cells before copulation and disappearing after it may facilitate sperm entry as well.

The genital pore has been shown here to be the site of exit of larvae from the maternal organism. Previously it has been suggested that in some species larvae stay inside the female until the latter is eaten by the host (Caullery 1961). It has also been suggested that larvae emerge from the female by rupture of the body (Malakhov 1990). It should be noted that muscle fibres, shown to be present in orthonectids (Slyusarev and Manylov 2001), do not take part in genital pore functioning. Although the genital pore in orthonectids seems to be organized rather primitively, being filled by just a few cells, it functions quite effectively, ensuring fertilisation and larval exit from the maternal body.

Acknowledgements. The greater part of this study was carried out in Southern Illinois University, Carbondale, Illinois through support obtained by the late Donald M. Miller. Unfortunately, his untimely death made it impossible to finish the work together with him. Thanks to support obtained for me by Reinhardt M. Kristensen, Zoological Museum, University of Copenhagen (ZMUC), the study could be completed in Denmark. I extend my sincere thanks to R.M. Kristensen for various kinds of help and useful discussions during my stay. Financial support for this study was provided by Russian grant RFFI 01-04-49788 and Universitety Rossii 07.01.055. 


\section{REFERENCES}

CAULLERY M. 1961: Classe des Orthonectides (Orthonectida Giard, 1877). In: P.-P. Grassé (Ed.), Traité de Zoologie. Tome 4, Fasc. 1. Masson, Paris, pp. 695-706.

CAULLERY M., MESNIL F. 1901: Recherches sur les Orthonectides. Arch. Anat. Microsc. 4: 381-470.

HALOTI S., VERNET G. 1995: The sexual reproduction of Intoshia linei (Orthonectida) endoparasite of Lineus ruber (Heteronemertea). Invertebr. Reprod. Dev. 25: 73-76.

KOZLOFF E.N. 1969: Morphology of the orthonectid Rhopalura ophiocomae. Parasitology 55: 171-195.

KOZLOFF E.N. 1971: Morphology of the orthonectid Ciliocincta sabellariae. Parasitology 57: 585-597.

KOZLOFF E.N. 1992: The genera of the phylum Orthonectida. Cah. Biol. Mar. 33: 377-406.

MALAKHOV V.V. 1990: [Enigmatic groups of marine invertebrates.] Nauka, Moscov, 144 pp. (In Russian.)
NOUVEL H. 1935: Application des techniques d'imprégnation argentique a l'étude systématique des Orthonectides. Bull. Biol. Fr. Belg. 69: 503-507.

SLYUSAREV G.S. 1994: Fine structure of the female Intoshia variabili (Alexandrov \& Slyusarev) (Mesozoa. Orthonectida). Acta Zool. (Stockh.) 75: 311-321.

SLYUSAREV G.S., MANYLOV O.G. 2001: General morphology of the muscle system in the female orthonectid, Intoshia variabili (Orthonectida). Cah. Biol. Mar. 42: 239-242.

SLYUSAREV G.S., MILLER, D.M. 1998: Fine structure of the mature plasmodium of Intoshia variabili (Phylum Orthonectida), a parasite of the plathelminth Macrorhynchus crocea. Acta Zool. (Stockh.) 79: 319-328. 